\title{
A Sectoral Explanation of Per Capita Income Convergence and Divergence: Estimating Verdoorn's Law for Countries at Different Stages of Development
}

\author{
Guilherme R. Magacho \\ , Department of Land Economy, University of Cambridge. \\ E-mail: guilherme.magacho@gmail.com
}

\begin{abstract}
John S. L. McCombie
Fellow in Economics, Downing College and Director of the Cambridge Centre for Economic and Public Policy, Department of Land Economy, University of Cambridge. E-mail: jslm2@cam.ac.uk
\end{abstract}

\begin{abstract}
This paper estimates the Verdoorn law (the relationship between productivity and output growth) for manufacturing industries for 70 developed and developing countries. It tests the hypothesis that the various manufacturing industries exhibit different values of the Verdoorn coefficient and hence different degrees of increasing returns, broadly defined. The paper analyses especially whether or not these estimates vary according to the level of a country's economic development, controlling for such factors as human capital and the level of technology. It is found that this is the case. Countries in the early stages of development would benefit from specialising in lowtech manufacturing and consumption goods, as these industries have larger Verdoorn coefficients than in the more developed countries. However, as countries reach higher stages of development, it is advantageous for them specialize in the high-tech manufacturing industries and the capital goods industries. These have relatively high values of the Verdoorn coefficient compared with the less developed countries. It is concluded that the composition of industries that leads to the fastest growth of manufacturing productivity differs depending upon the level of economic development.
\end{abstract}

Keywords: Verdoorn's law, productivity growth, increasing returns, manufacturing, structural change.

IEL Classification: E12, 033, 04 


\section{Introduction}

A major explanation as to whether or not countries' income per capita converge or diverge focuses upon on whether increasing returns to scale, broadly defined, exist. Due to the assumption of constant returns to scale and a common technology, neoclassical growth models (Solow, 1956; Swan, 1956) predict that the per capita income of countries tend to converge in the long run. The new growth models (also known as the neoclassical endogenous growth models) extend this framework by assuming that the rate of technological change is, to a large extent, determined endogenously. According to this approach, countries exhibit increasing returns to scale due either to externalities generated by capital accumulation (Romer, 1986) or to the amount of resources devoted to R\&D and education (Lucas, 1988; Romer, 1990). Consequently, these models suggest that the per capita income of countries may tend to diverge in the long run.

Neoclassical endogenous growth models, however, neglect two main issues concerning the explanation of the disparate productivity growth rates of countries. First, in a similar manner to the Solow growth model, endogenous growth models assume that the explanation for the differences between countries' growth rates is ultimately related to the supply side. This includes the rate of capital accumulation and the value of R\&D expenditures, both ultimately determined by the volume of savings. Consequently, demand-constraints do not have any role to play in these models (Dutt, 2006). Secondly, the endogenous growth models pay no attention to the sectoral composition of production. Although they emphasise the importance of some activities, such as R\&D, the degree of increasing returns is not assumed to be associated with any specific sector, such as manufacturing, agriculture or services (Palma, 2005). In contrast to the neoclassical models, Kaldor $(1966 ; 1972)$ argued that individual sectors have different degrees of (static and dynamic) increasing returns to scale. Consequently, a country's sectoral structure of production influences its growth rate. It follows that neither convergence nor divergence is a rule - it will partly depend on the degree of specialization of a country's industries.

Kaldor's sectoral approach to increasing returns to scale is at the heart of Verdoorn's law. According to this law, a faster growth of manufacturing, unlike that of the primary and tertiary sectors, promotes a faster growth of productivity (Kaldor, 1966). Consequently, specialisation in this sector is important to boost a country's growth rate. 
Verdoorn (1949) emphasised a long-term association between a faster growth of manufacturing output and that of productivity. He presented regression results for a crosssection of countries for the inter-war period which showed that when productivity was regressed on output growth, the regression (Verdoorn) coefficient took a value of about a half. Kaldor (1966) went further and argued that this represented a causal relationship. According to him, a faster output growth causes a faster growth of productivity due to static and dynamic increasing returns, the later including induced technical progress (McCombie and Thirlwall, 1994: 168).

In his 1966 inaugural lecture, Kaldor argued that the UK's slow rate of economic growth in the early post-war period, compared with the continental European counties, was due to its "premature maturity". The UK had encountered labour shortages before the other advanced countries and this had constrained the rate of growth of its manufacturing, and, hence, productivity growth. (Kaldor, 1975) subsequently changed his mind for the UK, considering that its slow rate of growth was due to its balance-of-payments constraint.) Kaldor also extended this argument to countries at different stages of development (Kaldor, 1966; 1967). This also involves a consideration of the fact that different industries comprising manufacturing, such as the capital goods industry, might have different degrees of increasing returns and income elasticities of demand. These may also vary according to a country's stage of development. Individual industries have different advantages of production and demand factors, such as market extension, skilled labour and innovation. Consequently, one cannot expect that these industries will have the same characteristics in both developing and developed countries.

This paper analyses manufacturing industries in terms of the size of their dynamic increasing returns to scale across countries, controlling for their level of economic development. This is proxied by their GDP per capita. The aim is to identify those industries that exhibit a larger degree of increasing returns, and hence which are able to boost economic growth both for developing and developed countries. This analysis aims to test the importance of the sectoral structure of an economy for productivity growth. It will also consider how specialisation in some industries can boost overall industrial productivity growth in the long run, and whether or not it depends on the country's stage of development.

Several studies have analysed the existence of increasing returns across manufacturing industries, for example: McCombie and de Ridder (1984), McCombie 
(1985), and, more recently, Angeriz et al. (2008, 2009), Romero and McCombie (2016), and Magacho and McCombie (2017). Essentially, they found evidence of large increasing returns to scale at both the total and the individual industry level, especially when the specification estimates dynamic increasing returns. However, these studies use data for the regions of a specific country or a group of countries (e.g., the states of the USA or the regions of the European Union) or for the developed countries. These are all at roughly the same level of economic development. Consequently, it is not possible, from these studies, to draw any significant conclusions about how the importance of various industries vary according to a country's stage of economic development. In this vein, this paper goes further and analyses the degree of increasing return for both developed and developing countries at the industry level, extending the study of Magacho and McCombie (2017). Verdoorn's law is estimated across a range of 70 countries, including those with high, middle and low per capita income levels, in order to determine how increasing returns to scale vary with the level of development. This will contribute to an explanation of the convergence (or divergence) of the productivity growth of countries by focusing on the sectoral composition of their manufacturing industries.

The paper is organised as follows. The next section presents a brief discussion on the debate on the demand and supply-side specifications of Verdoorn's law. Section 3 discusses the methods used to estimate the law, incorporating human capital and technological gaps into the original specification and allowing for the different level of development. Section 4 presents the estimates of these various specifications. Section 5 discusses the consequence of this paper's findings for the literature on economic growth and provides the concluding remarks.

\section{Verdoorn's law and the supply and demand-oriented approaches}

One important issue that is still relevant at the present time concerning the specification of the Verdoorn law was debated in the 1970s between Rowthorn (1975a \& b) and Kaldor (1975). The simplest specification of the Verdoorn law is the regression of productivity growth $(q)$ on output growth $(y)$, namely, $q=\alpha+\beta y$.

More recent specifications include the growth of the capital stock and other controlling variables. 
Cross-regional or cross-country growth rates averaged over several years are usually used in the estimation of the law. The use of time-series data merely captures, to a large extent, the short-run procyclical fluctuation in productivity growth due to labour hoarding, etc., inherent in Okun's law (1962). The fact that, in the short-run, a onepercentage point increase in output growth over the cycle is associated with half a percentage point increase in productivity growth does not necessarily reflect the degree of returns to scale (McCombie and de Ridder, 1983) .

Rowthorn (1975a) found that using employment growth as the regressor, the data for developed countries for the early post-war period did not refute the hypothesis of constant returns to scale, when Japan was dropped as an outlier.

The outcome of the interchange is that if growth is subject to a cumulative causation process, then a faster growth of output will lead to a faster growth of productivity. This will, in turn, improve price competitiveness and further increase the growth of output (Salter 1966). The upshot is that estimating the Verdoorn law by OLS is likely to lead to simultaneous equation bias and an instrumental variable (IV) estimator should be used (Rowthorn, 1975b). But matters are not so straightforward. McCombie (1985) used an IV approach and found that the direction of normalisation (i.e. whether output or employment growth is specified as the regressor) still made a significant difference. He suggested using an orthogonal regression, although this is not without its problems and has not been followed in the subsequent literature. ${ }^{2}$

Angeriz et al. (2008, 2009) and Magacho and McCombie (2017) estimated the Verdoorn law based on both the demand- and supply-side specifications. Angeriz et al. (2008, 2009) using IV methods and regional data, found values for the degree of increasing returns statistically different from the unity when output growth is the regressor, but nonsignificant results when the growth rates of factor inputs are the regressor. Magacho and McCombie (2017) corroborated these findings for the large majority of individual manufacturing industries, using international data and the System GMM estimator. These studies show that if one assumes that the correct method of normalisation is to regress productivity on output growth, such as specified in the demand-side version, total manufacturing and most of its individual industries are subject to increasing returns. But if one assumes that the growth rates of inputs should be specified as the regressors, such as assumed by the supply-side view, the hypothesis of increasing returns is refuted. 
Consequently, the direction of normalisation has to be decided on a priori grounds. As noted above, the neoclassical approach assumes that savings determines investment and the growth of the labour supply is exogenous. Consequently, if this assumption is made the results of the supply-side specification will produce the more reliable estimates of the degree of increasing returns. The Kaldorian approach, on the other hand, sees investment as being induced by profits, rather than by an exogenously determined savings rate. Hence, as this view is considered more plausible, the demand-side specification is the most appropriate and is used in this paper.

\section{Specification, data and sectoral aggregation}

\subsection{The demand-side version of Verdoorn's law}

On the one hand, Verdoorn (1949, Appendix) derived the Verdoorn law explicitly from an aggregate Cobb-Douglas production function and a number of studies have followed this approach. However, one the other hand, the aggregate production function is subject to serious aggregation problems (Felipe and Fisher, 2008), the limitations shown by the Cambridge capital theory controversies (Harcourt and Cohen (2003)) and serious problems concerning the interpretation of the empirical results posed by the use of value data, rather than physical data, which ideally should be used (Felipe and McCombie, 2013). Given these limitations, McCombie and Spreafico (2016) have shown how the Verdoorn law may be derived without recourse to the assumption of an aggregate production function.

Whichever interpretation is adopted, following Magacho and McCombie (2017), the following equation presents the demand-led version of the law using cross-sectional data:

$$
q=\alpha+\beta y+\gamma(k-y)
$$

where $q$ is again the rate of growth of productivity, $y$ is the rate of growth of output, $k$ is the rate of growth of capital, $\alpha$ is the exogenous rate of growth of productivity, $\beta$ measures the impact of output growth on productivity growth, and $\gamma$ measures the impact of the rate of change in capital-output ratio on productivity growth.

Productivity growth is explained by the three variables in equation (1), namely, exogenous productivity growth, the effect of output growth and the rate of growth of the 
capital-output ratio. If it is assumed that, in the long run, capital and output grow at the same rate, (one of Kaldor's (1961) stylised facts), equation (1) reduces to Verdoorn's original formulation of the law (Verdoorn, 1949). Alternatively, changes in the capitaloutput ratio can be used as a control for estimating the direct impact of output on productivity growth. In the approach adopted here, the law is specified as allowing for changes in capital-output ratio and the Verdoorn coefficient. The latter measures the longterm impact of output growth on productivity growth and is given by the estimate of $\beta$.

As discussed above, this specification normalises the equation with output growth as the regressor. This implies that demand factors are the main drivers of the growth process. By estimating equation (1), we obtain the degree of dynamic increasing returns under the assumption that output growth is primarily determined by demand factors, and the growth in the use of the factors of production (capital and labour) are determined by the growth of output. This is in accord with the demand-side (or Kaldorian) version of Verdoorn's law.

As the sample includes a large number of developing countries, a variable for the level of human capital needs to be included in the regression. We follow the standard approach and include the degree of schooling to capture these differences. Amable (1993), for example, argues that the level of education (not simply its growth rate) accelerates the growth of productivity. According to him, a higher level of schooling enhances the rate of productivity growth because it increases the technical competence of labour force that, inter alios, is essential for borrowing external technologies and for developing the country's own technology.

Another important issue to be considered is that the technological gap may affect productivity growth. There are many authors who argue that countries below the technological frontier have the possibility of imitating and thus growing faster due to the diffusion of innovations (see, for example, Barro and Sala-i-Martin (1997), Rodrick (2013), Fagerberg (1994) and Fagerberg and Verspagen (2002)).

The technological gap is proxied by the degree of sophistication of a country's sectoral exports in comparison to the US. Following Hausmann et al. (2007), a proxy for the technological complexity of sectoral exports is calculated based on the income per capita of the countries that export similar goods. As in Magacho and McCombie (2017), first, the weighted average of the income per capita of the countries that export each good is calculated, as follows: 


$$
P R O D Y_{k}=\sum_{j} \frac{X_{j k} / X_{j}}{\sum_{j} X_{j k} / X_{j}} G D P p c_{j}
$$

where GDPpc is the GDP per capita, and X are exports. The subscripts $\mathrm{j}$ stands for the country and $\mathrm{k}$ stands for the product. Then, the technological complexity of exports for the sector $i$ is calculated by the weighted average of each good, PRODY, as follows:

$$
E X P Y_{j i}=\sum_{k} \frac{X_{j k}}{X_{j i}} P R O D Y_{k}
$$

where $k$ stands for all products classified inside sector $i$. Finally, for each sector $i$, the variable for the technological gap, $G$, is defined as the ratio between the sectoral $E X P Y$ of the country under consideration for the current year divided by the EXPY of the United States for the same sector in the same year.

One of the usual assumptions behind the estimation of the Verdoorn's law through panel-data models using countries in a cross-section is that the Verdoorn coefficient does not vary according to countries' characteristics.

However, there are theoretical reasons for believing that the degree of increasing returns is not identical for countries at different stages of development, especially when the Verdoorn law is estimated at the individual industry level. Skilled workers, for example, might be more important for some fabricating activities than others according to a country's stage of development. On the one hand, it could be expected that more complex activities, which demand more qualified workers, are subject to higher increasing returns to scale in the more advanced economies than in the developing countries. On the other hand, a greater pool of less qualified workers is important for labour-intensive activities, so that the growth of activity is not constrained by labour availability. Hence, these activities might have higher increasing returns in less developed economies.

Taking advantage of having a dataset, discussed below, with countries in different stages of development, output growth can be interacted with countries' income per capita in order to obtain the Verdoorn coefficient according to the countries' stages of development. Based on this interaction, Verdoorn's law is estimated allowing for changes in the coefficient according to countries' income per capita (as a proxy for their stage of development), through heterogeneous regressions. ${ }^{3}$ This estimation sheds light on the 
importance of the sectoral structure for a country's development, as different industries can have different degrees of increasing returns, according to a country's per capita income. Consequently, the following equation is estimated:

$$
\begin{aligned}
& q_{j}=\beta_{0}+\delta q_{j, t-1}+\beta_{1} y_{j, t}+\beta_{2} y_{j, t-1}+\beta_{3} y_{j, t} \ln \left(G D P p c_{j, \bar{t}}\right)+ \\
& +\beta_{4} y_{j, t-1} \ln \left(G D P p c_{j, \bar{t}}\right)+\beta_{5}\left(k_{j, t}-y_{j, t}\right)+\beta_{6} G_{j, t}+\beta_{7} H_{j, t}+\varepsilon_{j, t}
\end{aligned}
$$

where $H_{j, t}$ is country $j$ 's level of schooling, $G_{j, t}$ is the technological gap, and $G D P p c_{i \bar{t}}$ is GDP per capita at a specific point of time, denoted by $\bar{t}$ and is 2005 .

The Verdoorn coefficient provided by this estimation procedure is obtained through the interaction of output with a country's per capita income, which means that it is not a parameter, but a function of a country's per capita income. Thus, rather than one value, estimates for the Verdoorn coefficient that depends on the countries' GDP per capita is given by as follows:

$$
\beta=\frac{\beta_{1}+\beta_{2}+\left(\beta_{3}+\beta_{4}\right) \ln \left(G D P p c_{j, \bar{t}}\right)}{1-\delta}
$$

We next turn to the discussion of the data and their sources.

\subsection{Data and sectoral aggregation}

The data sources and the level of aggregation are the same as used in Magacho and McCombie (2017) and are repeated here for convenience. The Verdoorn law was estimated using growth rates averaged over seven years, in order to remove any short-term cyclical effects associated with Okun's law, noted above. The data for employees and value added are from the UNIDO Industrial statistics database at the 2-digit International Standard Industrial Classification, revision 3 (UNIDO-INDUSTAT2). In the absence of industry-specific price deflators, the GDP price deflators had to be used and these are taken from the Penn World Table (PWT), version 7.1 (Helson et al 2012). The fixed capital stocks, following the approach of Angeriz et al (2008), were calculated from the data on the gross fixed capital formation (GFCF) at the ISIC 2-digit level taken from the UNIDO data base. The investment deflators are from the 
PWT 7.1. The maximum availability of data was from 1963-2009 for 38, mainly developed, countries. Data at the 2-digit ISIC were aggregated to give the longest available time span.

The sectors used are the following: food, beverages and tobacco products [Food]; textiles, wearing apparel and leather products [Textiles]; wood and paper [Paper]; fuels [Fuels]; chemicals, rubber and plastic [Chemicals]; non-metallic mineral products [Nonmetallic]; basic and fabricated metals [Metals]; machinery, equipment, office and computing machinery [Machinery]; electrical machinery, communication, medical, precision and optical equipment [Electrical]; motor vehicles and other transport equipment [Transport]; and furniture and other manufacturing products [Others].

The empirical analysis also considers the grouping of these sectors according to the UNIDO (2013:205) classification into low-tech [LT] and high-tech [HT] industries. The LT industries are Food, Textiles, Paper, Fuels, Non-metallic, Metals and Others and the HT industries are Chemical, Machinery, Electrical and Transport. The groupings according to demand are as follows. Natural resource based industries [NR] comprise Food, Paper, Fuels, Non-Metallic and Metals, consumption goods [CG] are Textiles, Transport and Others and capital goods [KG] are Machinery and Electrical. As Chemicals cannot be assigned solely to either the CG or the KG sectors, this industry is omitted. Moreover, because many sectors include capital and consumption, such as Electrical, which includes electrical machinery and communication appliances, there is a significant degree of arbitrariness in this classification. ${ }^{4}$

\section{The Empirical results}

\subsection{Verdoorn's law at the industry level}

Tables 1 to 4 and Figures 1 to 2 present the full results for the Verdoorn coefficient obtained by regressing equation (4) and evaluated at three different values of the GDP per capita. The estimation method is the System GMM. ${ }^{5}$ Table 1 presents the estimates of the Verdoorn coefficient by the level of economic development with no controls and with control variables for the degree of human capital (proxied by the level of schooling) and the technological gap (defined as the ratio between the sectoral EXPY of the country under consideration for the current year divided by the EXPY of the United States for the same sector in the same year). The Verdoorn coefficient is calculated using equation (5) and the values for the low-income countries is where GDP per capita is taken as $\$ 2,500$ in 2005 . 
The middle-income country estimates are where the GDP per capita is $\$ 10,000$ and highincome countries are where per capita income is than $\$ 40,000 .{ }^{6}$ As can be seen from Table 1 , most sectors have positive Verdoorn coefficients, which are statistically significant at the $5 \%$ confidence level, irrespective of the countries' income per capita. The only case in which this value is negative is for Textiles for the high-income countries, indicating the presence of diminishing returns to scale. In all other cases, the Verdoorn coefficient indicates that production is subject to dynamic increasing returns to scale.

From Table 1, it may be seen that for the majority of sectors, the value of the Verdoorn coefficient is higher for low-income countries than for high-income countries. Turning first to the case where there are no controls, for total manufacturing, the Verdoorn coefficient falls from 0.656 for low-income countries to about half this value for highincome countries (0.319). The value for Textiles, especially, declines rapidly as per capita income increases, from 0.628 to -0.382 . The latter value suggests marked decreasing returns to scale.

Controlling for the technological gap and the level of schooling does not make a dramatic difference to the results. The value of the Verdoorn coefficient for the low-income countries has now increased to 0.734 while that of the high-income countries remains largely unchanged at 0.329 . The value for Textiles for the high-income countries is somewhat larger at -0.165 (compared with -0.382). The Verdoorn coefficient for Electrical is now approximately constant taking values around 0.31 , rather than increasing from 0.240 to 0.311 with per capita income. The Non-Metallic industry, rather than declining from 0.633 (low-income) to 0.530 (high-income) when there are no controls, now increases from 0.535 to 0.608 .

[Table 1 - Verdoorn coefficient by industry, according to the countries' level of development]

Over all, these results demonstrate that almost every sector exhibits large degrees of increasing returns for countries in the early stages of development, but in most sectors, as the countries' per capita incomes increase, the value of the Verdoorn coefficient decreases. However, even for countries at the later stages of development there are, nevertheless, still a large number of high values. 


\subsection{Technological Intensity}

One of the main sources of dynamic increasing returns at the industry level results from technological search and the diffusion of knowledge. According to Fagiolo and Dosi (2003:239), "technological advances are endogenously generated through resourceexpansive search undertaken by multiple agents". Therefore, one may expect a larger degree of increasing returns in sectors with a greater technological intensity, as expenditure on research and technological diffusion are the main drivers of productivity growth in these sectors. Moreover, it is also plausible to expect a larger Verdoorn coefficient as development occurs, as expenditures on R\&D and innovation activities are likely to be positively related to the level of GDP per capita.

In order to evaluate how the degree of increasing returns among sectors varies with different levels of technological intensity, the various industries were aggregated according to their technological intensity into high- and low-tech manufacturing. The same methodology used before to estimate the Verdoorn coefficient according to countries' GDP per capita is applied here and the results are reported in Table 2 and shown in Figures 1 and 2.

[Table 2 - Verdoorn coefficient, by technological intensity, according to countries' per capita income level]

Table 2 presents the results where again there are no controls and also controls for both the technological gap and schooling. The results of the first estimation with no controls show that there is no difference between the estimates of the Verdoorn coefficient for the low-tech and high-tech industries for countries at a low level of economic development. They take values of 0.495 and 0.488 respectively, but interestingly, when they aggregated to give manufacturing, the Verdoorn coefficient rises to 0.656 .

However, as GDP per capita increases, the Verdoorn coefficient of high-tech industries increases (from 0.488 to 0.578 ) and the Verdoorn coefficient of low-tech industries decreases (from 0.495 to 0.407 ). Hence, the degree of increasing returns is higher in high-tech than in low-tech industries for middle- and high-income countries. It means that specialisation in low-tech industries increases the productivity growth only for low-income countries. Conversely, for middle- and for high-income countries, industries with high-technological intensity are those capable of boosting productivity growth the 
most, as they have the highest Verdoorn coefficient. The estimates of Verdoorn coefficient, controlling for both technological gap and level of schooling, generally corroborate these findings. The exception is that the Verdoorn coefficient for high-tech industries falls slightly with per capita income. Nevertheless, the Verdoorn coefficient is still higher for high-tech than the low-tech industries in the middle-income and high-income countries.

Figure 1 shows the value of the Verdoorn coefficient at various levels of GDP per capita. It can be see how specialisation in low-tech industries benefits countries in the early stages of development. However, to take advantage of this important source of productivity growth, countries in advanced stages of development need to specialise in high-tech industries, as these industries exhibit the highest Verdoorn coefficients.

The Verdoorn coefficient for the low-tech industries is 0.70 for countries in the lowest per capita income band and it falls to 0.34 for countries that have a per capita income of US\$40,000. Consequently, the regression results that control for the technological gap and the level of schooling clearly shows that countries should promote high-tech industries when they reach high levels of per capita income, otherwise they will not benefit from dynamic increasing returns to scale to as great an extent as they might.

[Figure 1 - Verdoorn coefficient, by technological intensity, according to countries' per capita income level (controlling for the technological gap and schooling)]

\subsection{Categories of demand}

A complementary approach to understanding the differences in the degree of dynamic increasing returns among industries is based on the various categories of demand. In other words, whether the sectors produce consumption goods, capital goods or are based on natural resources. Lundvall (1992) argued that the capital goods producers are responsible for most of the innovations in the economy, and they are central to the process of technological diffusion. Furthermore, as stressed by Kaldor $(1966,1967)$, capital investment is an important source of demand for countries at the most advanced stages of development. This is because a developed manufacturing sector largely provides the output on which capital investment is spent. Hence, manufacturing "thereby generates a demand for its own products in the very process of supplying them" (Kaldor, 1966 in Targetti and Thirlwall, 1989, p.295). Kaldor considers that as countries develop, there will 
be reduced imports of manufactured goods and an increase in the imports of machinery and equipment. The next stage of development is for countries to become net exporters of manufactured goods and for there to be import substitution for capital goods. The final stage of what he terms "explosive growth" is when a country becomes a net exporter of capital goods, for the reasons outlined above. Hence, the capital goods industry is an important sector in the growth process.

In order to estimate the degree of dynamic increasing returns according to categories of demand, industries are grouped into three categories: natural resource based manufacturing [NR], consumption goods [CG] and capital goods [KG]. Verdoorn's law is estimated using the same methodology as employed before with the aim of identifying how the coefficient varies for countries in different stages of development.

Table 3 and Figure 2 present the estimates of the Verdoorn coefficient for each of these categories according to the countries' income per capita. From Table 3, it can be seen that it makes little significant difference as to whether or not the technological gap and schooling controls are included in the estimation of the Verdoorn law. Consequently, we confine our attention to the case where technological gap and the schooling controls are included in the regression.

[Table 3 - Verdoorn coefficient, by categories of demand, according to countries' per capita income in 2005]

Turning first to the capital goods industries, it can be seen from Figure 3 that that the Verdoorn coefficient increases with the level of economic development. The coefficient is 0.353 when per capita income is $\$ 2,500$ and it increases to 0.471 for the high-income countries.

The natural resource industries have a very high Verdoorn coefficient at low levels of development taking a value of 0.843 at GDP per capita which steadily declines to 0.406 at high levels of per capita income.

The consumption goods industries present something of a conundrum. They have a relatively large Verdoorn coefficient at low levels of per capita income and rapidly falls until it is very low for the developed countries. This is because consumption goods are defined to include Textiles and as we have seen above, the Verdoorn coefficient of Textiles declines very rapidly with the degree of GDP per capita. 
[Figure 2 - Verdoorn coefficient, by categories of demand, according to countries' per capita income level (controlling for the technological gap and schooling)]

\section{Concluding remarks}

There is an important debate in economic theory about why some developing countries were able to achieve sustained high-growth rates and their incomes per capita have converged towards developed ones, and why others were not. This paper tried to assess this issue from a Kaldorian approach, which emphasises the importance of increasing returns to scale, broadly defined, for some sectors. More specifically, the degree of increasing returns was estimated according to the countries' stages of development using heterogeneous regressions.

The results confirm other findings that the individual industries exhibit large increasing returns to scale. This is regardless of whether or not controls for the technological intensity and schooling were used. It is also found that there is a great deal of variation between individual industries.

The main result of this study, however, is that Verdoorn coefficients vary according to a country's stage of development. It was found that the Verdoorn coefficient for most individual manufacturing industries decreases as a country's GDP per capita increases. This suggests that countries should specialise in manufacturing to take advantage of dynamic increasing returns, especially in the early stages of development.

In contrast to these findings, when the sectors are grouped according to their technological intensity and according to their categories of demand, it was found that countries in the early stages of development benefit from specialising in low-tech manufacturing and consumption goods, to the extent that they have relatively higher Verdoorn coefficients. However, as countries reach higher stages of development, it is important to promote structural changes in favour of high-tech manufacturing sectors and the production of capital goods. Although these industries present relatively low dynamic increasing returns for low-income countries, their degree of increasing returns is higher for high-income countries. Because technological search and the diffusion of knowledge are more important for these industries, and countries at a higher stage of development 
have a greater ability to spend on these activities, they can benefit the most by specialising in these industries.

These findings can explain why industrial policies that promote changes from lowtech manufacturing and consumption goods production to high-tech manufacturing and capital goods industries are important to reduce the per capita income gap between countries. These results are especially important for countries in the intermediate stages of development. It shows that promoting manufacturing is important for countries in the early stages of development. In particular, it is important to promote labour-intensive activities, such as Textiles. However, when a country reaches an intermediate stage of development, specialising in manufacturing is not enough. In order to increase productivity growth, it is necessary to promote structural change that increases the capital goods industries and industries with a high technological intensity.

\section{References}

Agung, I.G.N. (2014), Panel Data Analysis using EViews, Chichester, UK: John Wiley and Sons, Ltd.

Amable, B. (1993), Catch up and Convergence: a Model of Cumulative Growth, International Review of Applied Economics, 7(1):1-25.

Angeriz, A., J.S.L. McCombie and M. Roberts (2008), New Estimates of Returns to Scale and Spatial Spillovers of EU Regional Manufacturing, 1986-2002, International Regional Science Review, 31(1):62.

Angeriz, A., J.S.L. McCombie and M. Roberts (2009), Increasing Returns and the Growth of Industries in the EU Regions: Paradoxes and Conundrums, Spatial Economic Analysis, $4(2): 127$

Arellano, M., and Bond, S. (1991), Some tests of specification for panel data: Monte Carlo evidence and an application to employment equations, Review of Economic Studies, 58: 277-297.

Arrow, K.J. (1962), Economic Welfare and the Allocation of Resources for Invention, In: National Bureau of Economic Research, Inc. (NBER), The Rate and Direction of Inventive Activity: Economic and Social Factors, Princeton University Press. 
Baltagi, B.H. (2013), Econometric Analysis of Panel Data - fifth edition, Chichester, West Sussex: John Willy \& Sons.

Barro, R.J. and X. Sala-I-Martin (1997), Technological Diffusion, Convergence, and Growth, Journal of Economic Growth, 2(1): 1-27.

Blundell, R., and Bond, S. (1998), Initial conditions and moment restrictions in dynamic panel data models, Journal of Econometrics, 87: 115-143.

Cornwall, J. and W. Cornwall (2002), A demand and supply analysis of productivity growth, Structural Change and Economic Dynamics, 13:203

Fagerberg, J. (1994), Technology and International Differences in Growth Rates, Journal of Economic Literature, 32(3):1147-1175.

Fagerberg, J. and B. Verspagen (2002), Technology-gaps, Innovation-diffusion and Transformation: an Evolutionary Interpretation, Research Policy, 31: 1291-1304.

Fagiolo, G. and G. Dosi (2003), Exploitation, exploration and innovation in a model of endogenous growth with locally interacting agents, Structural Change and Economic Dynamics, 14:237.

Felipe, J. and F. M. Fisher (2008), Aggregation (production). Durlauf, S.N. and L. E. Blume (eds.), The New Palgrave Dictionary of Economics. Second Edition. Palgrave Macmillan,

Felipe, J. and J.S.L. McCombie (2013), The Aggregate Production Function and the Measurement of Technical Change: 'Not Even Wrong', Cheltenham, UK: Edward Elgar Publishing.

Cohen, A. J. and Harcourt, G. C. (2003), Retrospectives: whatever happened to the Cambridge capital theory controversies?. The Journal of Economic Perspectives, 17(1), 199-214.

Hausmann, R., J. Hwang and D. Rodrik (2007), What you export matters, Journal of Economic Growth, 12(1):1

Heston, A., R. Summers and B. Aten (2012), Penn World Table Version 7.1, Center for International Comparisons of Production, Income and Prices at the University of Pennsylvania.

Kaldor, N. (1961), Capital Accumulation and Economic Growth, In: F.A. Lutz and D.C. Hague (eds.) The Theory of Capital, London: Macmillan.

Kaldor, N. (1966), Causes of the Slow Rate of Economic Growth in the United Kingdom, Cambridge: Cambridge University Press reprinted in: F Targetti and A.P. Thirlwall (eds) (1980) The Essential Kaldor, London, Duckworth. 
Kaldor, N. (1967), Strategic factors in economic development, Ithaca, NY: New York State School of Industrial and Labor Relations, Cornell University.

Kaldor, N. (1972), The Irrelevance of Equilibrium Economics, The Economic Journal, 82(328):1237-1255.

Kaldor, N. (1975), Economic Growth and the Verdoorn Law - A Comment on Mr. Rowthorn's Article, The Economic Journal, 85: 891-896.

Kennedy, K. A. and A. Foley (1978), Industrial Development, The Economic and Social Research Institute, Dublin.

Lucas, R.E. (1988), On the Mechanics of Economic Development, Journal of Monetary Economics, 22(1):3.

Lundvall, B.A. (1992), National Final products of Innovation: Towards a Theory of Innovation and Interactive Learning, London: Frances Pinter.

Mankiw, N.G., D. Romer and D.N. Weil (1992), A Contribution to the Empirics of Economic Growth, The Quarterly Journal of Economics, 107(2):407.

Magacho, G.R. and J.S.L. McCombie (2017), Verdoorn's Law and Productivity Dynamics: an Empirical Investigation into the Demand and Supply Approaches, Journal of Post Keynesian Economics, forthcoming.

McCombie, J. S. L. (1981). What still remains of Kaldor's laws?. The Economic Journal, 91(361), 206-216.

McCombie, J.S.L. (1985), Increasing Returns and the Manufacturing Industries: Some Empirical Issues, The Manchester School of Economics and Social Studies, 53(1):55

McCombie, J.S.L. (2002), Increasing Returns and the Verdoorn Law from a Kaldorian Perspective, In: McCombie, J.S.L., M. Pugno and B. Soro, Productivity Growth and Economic Performance: Essays in Verdoorn's Law, New York: Palgrave Macmillan.

McCombie, J.S.L. and A.P. Thirlwall (1994), Economic Growth and the Balance-of-Payments Constraint, London: Macmillan Press LTD.

McCombie, J.S.L. and J. R. de Ridder (1983), Increasing Returns, Productivity, and Output Growth: the Case of United States, Journal of Post-Keynesian Economics, 5(3):372-387.

McCombie, J.S.L. and M.R.M. Spreafico (2016), Kaldor's 'Technical Progress Function' and the Verdoorn Law Revisited, Cambridge Journal of Economics, 40(6): 1117-1136.

Okun, A.M. (1962), Potential GNP: Its Measurement and Significance, Cowles Foundation for Research in Economics, New Haven CT: Yale University. 
Palma, G. (2005), Four Sources of 'De-industrialization and a New Concept of 'Dutch Disease', in: J.A. Ocampo (ed.) Beyond Reforms: Structural Reforms and Macroeconomic Vulnerability, Washington, DC: ECLAC.

Rodrik, D. (2013), Unconditional Convergence in Manufacturing, The Quarterly Journal of Economics, 128(1):165-204.

Romer, P.M. (1986), Increasing Returns and Long-run Growth, Journal of Political Economy, 94(5):1002-1037.

Romer, P. M. (1990), Endogenous technical change, Journal of Political Economy, 98(5):S71

Romero, J.P. and J.S.L. McCombie (2016), Differences in Increasing Returns Between Technological Sectors: A Panel Data Investigation Using the EU KLEMS Database, Journal of Economic Studies, 43(5):863-878.

Rowthorn, R.E. (1975a), What Remains of Kaldor's Law?, The Economic Journal, 85: 10

Rowthorn, R.E. (1975b), A Reply to Lord Kaldor's Comment, The Economic Journal, 85: 897

Solow, R. (1956), A Contribution to the Theory of Economic Growth, The Quarterly Journal of Economics, 70(1):65

Swan, T.W. (1956), Economic Growth and Capital Accumulation, Economic Record, $32(2): 33$

UNIDO (2012), Industrial Statistics Database 2-Digit Level ISIC Revision 3 (INDUSTAT2), Vienna: UNIDO.

UNIDO (2013), Industrial Development Report. Sustaining Employment Growth:The Role of Manufacturing and Structural Change, Vienna: UNIDO.

Verdoorn, P. J. (1949), Fattori che regolano lo sviluppo della produttivita` del lavoro, L'Industria, 1:3-10. English translation by A. P. Thirlwall, in: J.S.L. McCombie, M. Pugno and B. Soro (2002), Productivity Growth and Economic Performance: Essays in Verdoorn's Law, New York: Palgrave Macmillan.

Woodridge, J. M. (2002), Econometric Analysis of Cross Section and Panel Data, London: The MIT Press.

Young, A. (1928), Increasing returns and economic progress, Economic Journal, 38(152):527-542. 


\section{Notes}

1. After the early stage of development, where agriculture investment is the major important source of industrial growth, Kaldor $(1966,1967)$ define four stages of development based on foreign demand. First, a country has to promote import-substitution of consumption goods; second, promote exports of these goods; third, promote importsubstitution of capital goods; and, in the most advanced stage, promote exports of capital goods.

2. See McCombie (2002:95-96) for a detailed discussion about simultaneous equation bias in both estimations.

3. See Agung (2014:278-285) for a detailed presentation of this method and prior applications. Woodridge (2002:170-171) presents an example of this method for a panel data model.

4. An alternative classification was employed and, although slightly different, the results corroborate the main findings of the paper. In this alternative classification, Transport was classified as capital good rather than consumption good (because many capital goods, such as trains, rail lines, ships and others are included in this sector). Compared to the results presented in the paper, the Verdoorn coefficient is lower for Consumption Goods for all income levels, but it still decreases as countries reach higher income levels. For Capital Goods, the Verdoorn coefficient is very similar for all income levels and it is almost the same as those obtained when the classification employed in the paper was applyed.

5. The econometric method used was System GMM (Blundell \& Bond, 1998). This estimator was developed based on Arellano \& Bond's (1991) GMM estimator, which considers two sources of persistence over time: autocorrelation, due to the inclusion of lagged variables, and individual effects, controlling for heterogeneity between individuals. In these estimators, the orthogonality between the time-lagged variables and the disturbances generates additional instruments. Baltagi (2013) advocates that the difference between the Arellano-Bond GMM estimator and the Blundell \& Bond's System GMM (the one applied here) is that the latter enables causality analysis without the need for additional exogenous 
instrumental variables, as it uses lagged variables as instruments for level equations and level variables as instruments for lagged variables. Thereby, once the initial condition assumption is satisfied, there is no need for using exogenous regressors as instruments when the estimation method is the System GMM, because it uses lagged differences as instruments for equation in levels in addition to lagged levels as instruments for equations in first differences. The Hansen test is applied to verify whether the initial conditions are satisfied. This test analyses the orthogonality of the variables, and hence it is necessary to avoid over-identification or under-identification problems.

6. See Appendix for the complete results of all estimations. 
Table 1 - Verdoorn coefficient by industry, according to the countries' level of development

\begin{tabular}{|c|c|c|c|c|c|c|}
\hline & \multicolumn{3}{|c|}{ No controls } & \multicolumn{3}{|c|}{ Controls } \\
\hline & $\begin{array}{l}\text { Low- } \\
\text { income }\end{array}$ & $\begin{array}{l}\text { Middle- } \\
\text { income }\end{array}$ & $\begin{array}{l}\text { High- } \\
\text { income }\end{array}$ & $\begin{array}{l}\text { Low- } \\
\text { income }\end{array}$ & $\begin{array}{l}\text { Middle- } \\
\text { income }\end{array}$ & $\begin{array}{l}\text { High- } \\
\text { income }\end{array}$ \\
\hline Food & $\begin{array}{c}0.755 \\
(0.036)\end{array}$ & $\begin{array}{c}0.652 \\
(0.036)\end{array}$ & $\begin{array}{c}0.549 \\
(0.037)\end{array}$ & $\begin{array}{c}0.881 \\
(0.035)\end{array}$ & $\begin{array}{c}0.721 \\
(0.035)\end{array}$ & $\begin{array}{c}0.562 \\
(0.035)\end{array}$ \\
\hline Textiles & $\begin{array}{c}0.628 \\
(0.079)\end{array}$ & $\begin{array}{c}0.123 \\
(0.079)\end{array}$ & $\begin{array}{c}-0.382 \\
(0.080)\end{array}$ & $\begin{array}{c}0.652 \\
(0.068)\end{array}$ & $\begin{array}{c}0.244 \\
(0.068)\end{array}$ & $\begin{array}{l}-0.165 \\
(0.069)\end{array}$ \\
\hline Paper & $\begin{array}{c}0.460 \\
(0.047)\end{array}$ & $\begin{array}{c}0.450 \\
(0.048)\end{array}$ & $\begin{array}{c}0.439 \\
(0.048)\end{array}$ & $\begin{array}{c}0.538 \\
(0.057)\end{array}$ & $\begin{array}{c}0.491 \\
(0.057)\end{array}$ & $\begin{array}{c}0.443 \\
(0.058)\end{array}$ \\
\hline Fuels & $\begin{array}{c}1.100 \\
(0.152)\end{array}$ & $\begin{array}{c}0.929 \\
(0.153)\end{array}$ & $\begin{array}{c}0.758 \\
(0.154)\end{array}$ & $\begin{array}{c}1.075 \\
(0.148)\end{array}$ & $\begin{array}{c}0.925 \\
(0.149)\end{array}$ & $\begin{array}{c}0.774 \\
(0.150)\end{array}$ \\
\hline Chemicals & $\begin{array}{c}0.730 \\
(0.065)\end{array}$ & $\begin{array}{c}0.727 \\
(0.066)\end{array}$ & $\begin{array}{c}0.724 \\
(0.066)\end{array}$ & $\begin{array}{c}0.838 \\
(0.074)\end{array}$ & $\begin{array}{c}0.765 \\
(0.075)\end{array}$ & $\begin{array}{c}0.692 \\
(0.075)\end{array}$ \\
\hline Non-metallic & $\begin{array}{c}0.633 \\
(0.052)\end{array}$ & $\begin{array}{c}0.581 \\
(0.053)\end{array}$ & $\begin{array}{c}0.530 \\
(0.053)\end{array}$ & $\begin{array}{c}0.535 \\
(0.085)\end{array}$ & $\begin{array}{c}0.571 \\
(0.086)\end{array}$ & $\begin{array}{c}0.608 \\
(0.086)\end{array}$ \\
\hline Metals & $\begin{array}{c}0.748 \\
(0.055)\end{array}$ & $\begin{array}{c}0.676 \\
(0.055)\end{array}$ & $\begin{array}{c}0.604 \\
(0.056)\end{array}$ & $\begin{array}{c}0.852 \\
(0.049)\end{array}$ & $\begin{array}{c}0.696 \\
(0.049)\end{array}$ & $\begin{array}{c}0.540 \\
(0.050)\end{array}$ \\
\hline Machinery & $\begin{array}{c}0.595 \\
(0.132)\end{array}$ & $\begin{array}{c}0.484 \\
(0.132)\end{array}$ & $\begin{array}{c}0.373 \\
(0.133)\end{array}$ & $\begin{array}{c}0.622 \\
(0.178)\end{array}$ & $\begin{array}{l}0.503 \\
(0.18)\end{array}$ & $\begin{array}{c}0.383 \\
(0.181)\end{array}$ \\
\hline Electrical & $\begin{array}{c}0.240 \\
(0.055)\end{array}$ & $\begin{array}{c}0.275 \\
(0.055)\end{array}$ & $\begin{array}{c}0.311 \\
(0.056)\end{array}$ & $\begin{array}{c}0.308 \\
(0.051)\end{array}$ & $\begin{array}{c}0.313 \\
(0.051)\end{array}$ & $\begin{array}{c}0.318 \\
(0.051)\end{array}$ \\
\hline Transport & $\begin{array}{c}0.543 \\
(0.083)\end{array}$ & $\begin{array}{c}0.423 \\
(0.083)\end{array}$ & $\begin{array}{c}0.304 \\
(0.084)\end{array}$ & $\begin{array}{l}0.617 \\
(0.08)\end{array}$ & $\begin{array}{c}0.452 \\
(0.080)\end{array}$ & $\begin{array}{c}0.286 \\
(0.081)\end{array}$ \\
\hline Others & $\begin{array}{c}0.314 \\
(0.084)\end{array}$ & $\begin{array}{c}0.279 \\
(0.085)\end{array}$ & $\begin{array}{c}0.244 \\
(0.085)\end{array}$ & $\begin{array}{c}0.363 \\
(0.106)\end{array}$ & $\begin{array}{c}0.280 \\
(0.107)\end{array}$ & $\begin{array}{c}0.196 \\
(0.107)\end{array}$ \\
\hline Manufacturing & $\begin{array}{c}0.656 \\
(0.109)\end{array}$ & $\begin{array}{l}0.488 \\
(0.11)\end{array}$ & $\begin{array}{c}0.319 \\
(0.111)\end{array}$ & $\begin{array}{c}0.734 \\
(0.106)\end{array}$ & $\begin{array}{c}0.531 \\
(0.106)\end{array}$ & $\begin{array}{c}0.329 \\
(0.107)\end{array}$ \\
\hline
\end{tabular}

Notes: Standard errors in parentheses.

All coefficients except for Textiles for middle- and high-income countries in the first estimation and Textiles and Others for high-income countries in the second estimation are statistically higher than zero at the $5 \%$ significance level.

Verdoorn coefficient estimated through System GMM for 70 countries and the period is from 1963 to 2009 (unbalanced) based on seven-years growth rates. Low-income: GDPpc - USD 2,500 in 2005; Middle-income: GDPpc - USD 10,000 in 2005; Highincome: GDPpc - USD 40,000 in 2005. Controls: Schooling and Technological gap.

Sources: See text 
Table 2 - Verdoorn coefficient by technological intensity, according to countries' per capita income level

\begin{tabular}{l|ccc|ccc}
\hline & \multicolumn{3}{|c|}{ No controls } & \multicolumn{3}{c}{ Controls } \\
& $\begin{array}{c}\text { Low- } \\
\text { income }\end{array}$ & $\begin{array}{c}\text { Middle- } \\
\text { income }\end{array}$ & $\begin{array}{c}\text { High- } \\
\text { income }\end{array}$ & $\begin{array}{c}\text { Low- } \\
\text { income }\end{array}$ & $\begin{array}{c}\text { Middle- } \\
\text { income }\end{array}$ & $\begin{array}{c}\text { High- } \\
\text { income }\end{array}$ \\
\hline Low-tech & 0.495 & 0.451 & 0.407 & 0.699 & 0.519 & 0.338 \\
& $(0.139)$ & $(0.140)$ & $(0.141)$ & $(0.139)$ & $(0.140)$ & $(0.141)$ \\
High-tech & 0.488 & 0.533 & 0.578 & 0.554 & 0.539 & 0.525 \\
& $(0.082)$ & $(0.082)$ & $(0.083)$ & $(0.084)$ & $(0.085)$ & $(0.086)$ \\
Manufacturing & $\mathbf{0 . 6 5 6}$ & $\mathbf{0 . 4 8 8}$ & $\mathbf{0 . 3 1 9}$ & $\mathbf{0 . 7 3 4}$ & $\mathbf{0 . 5 3 1}$ & $\mathbf{0 . 3 2 9}$ \\
& $\mathbf{( 0 . 1 0 9 )}$ & $\mathbf{( 0 . 1 1 0 )}$ & $\mathbf{( 0 . 1 1 1 )}$ & $\mathbf{( 0 . 1 0 6})$ & $\mathbf{( 0 . 1 0 6}$ & $\mathbf{( 0 . 1 0 7 )}$ \\
\hline
\end{tabular}

Notes: Standard errors in parentheses.

All coefficients are statistically higher than zero at the 5\% significance level.

Verdoorn coefficient estimated through System GMM for 70 countries and the period is from 1963 to 2009 (unbalanced) based on seven-years growth rates. Low-income: GDPpc - USD 2,500 in 2005; Middle-income: GDPpc - USD 10,000 in 2005; High-income: GDPpc - USD 40,000 in 2005.

Controls: Schooling and Technological gap.

Sources: See text

Table 3 - Verdoorn coefficient by categories of demand, according to countries' per capita income in 2005

\begin{tabular}{|c|c|c|c|c|c|c|}
\hline & \multicolumn{3}{|c|}{ No controls } & \multicolumn{3}{|c|}{ Controls } \\
\hline & $\begin{array}{l}\text { Low- } \\
\text { income }\end{array}$ & $\begin{array}{l}\text { Middle- } \\
\text { income }\end{array}$ & $\begin{array}{l}\text { High- } \\
\text { income }\end{array}$ & $\begin{array}{l}\text { Low- } \\
\text { income }\end{array}$ & $\begin{array}{l}\text { Middle- } \\
\text { income }\end{array}$ & $\begin{array}{l}\text { High- } \\
\text { income }\end{array}$ \\
\hline \multirow[t]{2}{*}{ Consumption Goods } & 0.322 & 0.283 & 0.243 & 0.481 & 0.377 & 0.274 \\
\hline & $(0.068)$ & $(0.069)$ & $(0.069)$ & $(0.063)$ & $(0.064)$ & $(0.064)$ \\
\hline \multirow[t]{2}{*}{ Capital Goods } & 0.331 & 0.384 & 0.436 & 0.353 & 0.412 & 0.471 \\
\hline & $(0.086)$ & $(0.087)$ & $(0.088)$ & $(0.089)$ & $(0.089)$ & $(0.090)$ \\
\hline \multirow[t]{2}{*}{ Natural Resources } & 0.722 & 0.578 & 0.433 & 0.843 & 0.624 & 0.406 \\
\hline & $(0.048)$ & $(0.049)$ & $(0.049)$ & $(0.043)$ & $(0.044)$ & $(0.044)$ \\
\hline \multirow[t]{2}{*}{ Manufacturing } & 0.656 & 0.488 & 0.319 & 0.734 & 0.531 & 0.329 \\
\hline & $(0.109)$ & $(0.110)$ & $(0.111)$ & $(0.106)$ & $(0.106)$ & $(0.107)$ \\
\hline
\end{tabular}

Notes: Standard errors in parentheses.

All coefficients are statistically higher than zero at the 5\% significance level.

Verdoorn coefficient estimated through System GMM for 70 countries and the period is from 1963 to 2009 (unbalanced) based on seven-years growth rates. Low-income: GDPpc - USD 2,500 in 2005; Middleincome: GDPp - USD 10,000 in 2005; High-income: GDPpc - USD 40,000 in 2005. Controls: Schooling and Technological gap.

Sources: See text 
Figure 1 - Verdoorn coefficient by technological intensity, according to countries' per capita income level (controlling for the technological gap and schooling)

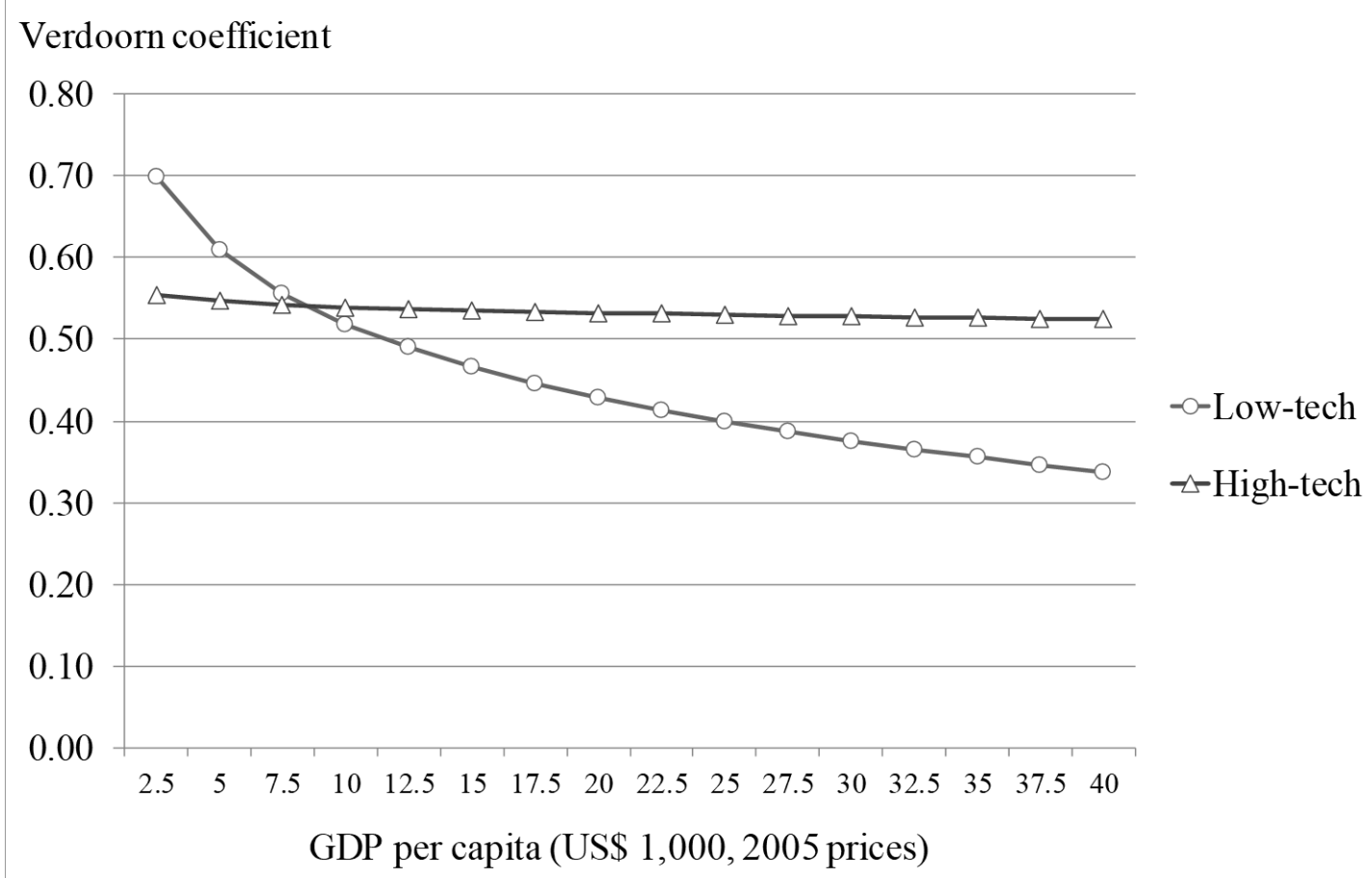


Figure 2 - Verdoorn coefficient by categories of demand, according to countries' per capita income level (controlling for the technological gap and schooling)

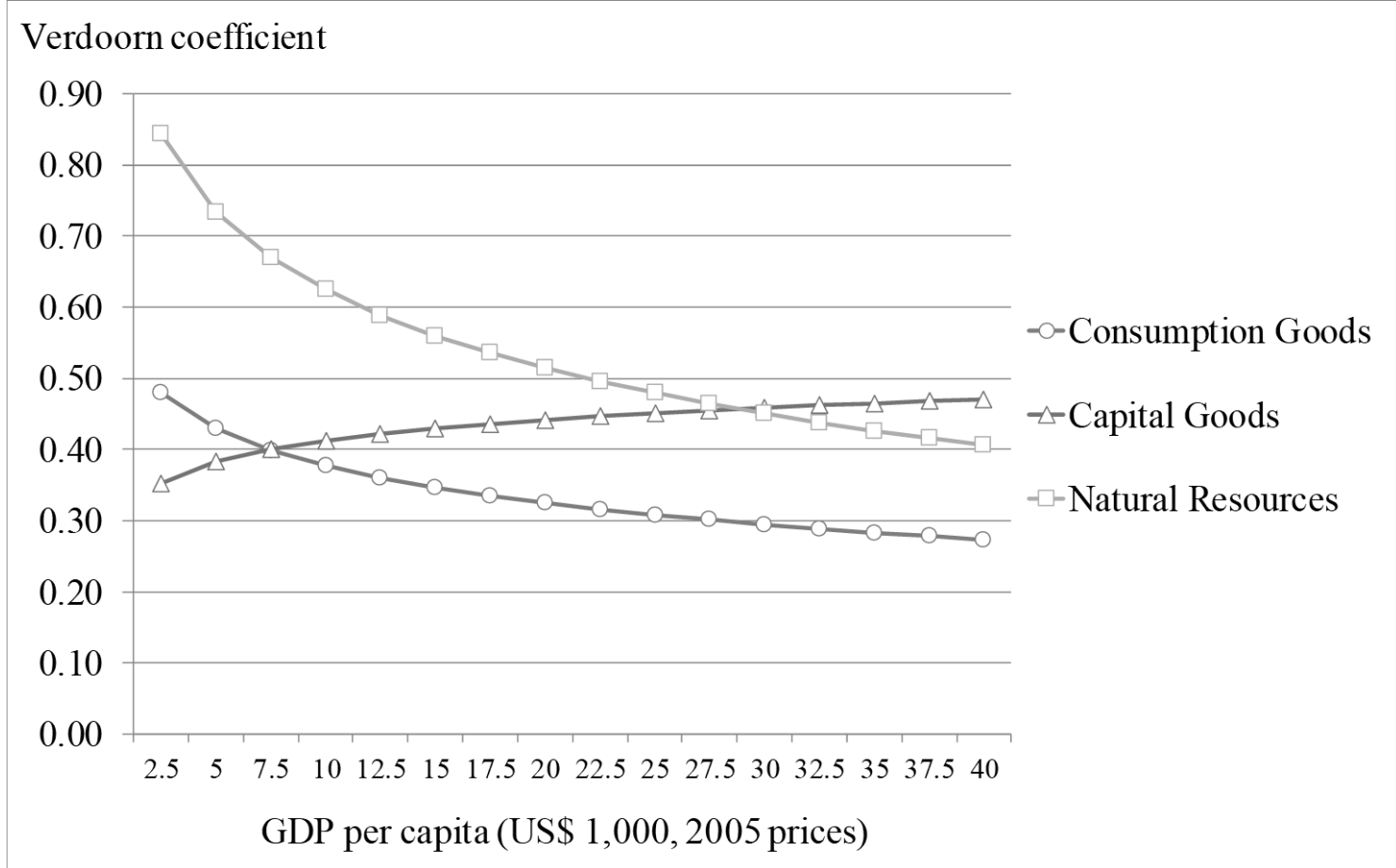




\section{Appendix}

Table B.1 - Estimation of Verdoorn's law through Sys-GMM by industry, no controls

Table B.2 - Estimation of Verdoorn's law through Sys-GMM by industry, controlled for schooling and tech gap

Table B.1 - Estimation of Verdoorn's law through Sys-GMM by industry, no controls

\begin{tabular}{|c|c|c|c|c|c|c|c|c|c|c|}
\hline & $q_{\text {Food }}$ & $q_{\text {Textiles }}$ & $q_{\text {Paper }}$ & $q_{\text {Fuels }}$ & $q_{\text {Chemicals }}$ & $q_{\text {Non-Met }}$ & $q_{\text {Metals }}$ & $q_{\text {Machinery }}$ & $q_{\text {Transport }}$ & qothers \\
\hline \multirow[t]{2}{*}{$q_{i, t-1}$} & 0.205 & $0.489 * *$ & 0.045 & 0.338 & $0.417 * * *$ & $0.366^{*}$ & -0.025 & -0.006 & 0.008 & 0.143 \\
\hline & $(0.193)$ & $(0.200)$ & $(0.095)$ & $(0.450)$ & $(0.094)$ & $(0.219)$ & $(0.157)$ & $(0.048)$ & $(0.117)$ & $(0.154)$ \\
\hline \multirow{2}{*}{$y_{i}$} & $0.758 * * *$ & $2.417 * * *$ & $0.839 *$ & $2.024 * *$ & $1.111 * * *$ & $1.042 * *$ & $1.784 * * *$ & 1.183 & $1.387 * * *$ & 1.122 \\
\hline & $(0.284)$ & $(0.528)$ & $(0.495)$ & $(0.985)$ & $(0.407)$ & $(0.450)$ & $(0.570)$ & $(1.337)$ & $(0.399)$ & $(0.847)$ \\
\hline \multirow[t]{2}{*}{$y_{i, t-1}$} & 0.305 & -0.642 & -0.345 & -0.659 & -0.676 & $-0.457 *$ & $-0.603 *$ & 0.046 & $-1.347 * * *$ & -0.079 \\
\hline & $(0.266)$ & $(0.432)$ & $(0.233)$ & $(0.856)$ & $(0.435)$ & $(0.244)$ & $(0.339)$ & $(0.768)$ & $(0.494)$ & $(0.300)$ \\
\hline \multirow[t]{2}{*}{$y_{i} \ln \left(Y_{p c}\right)$} & -0.003 & $-0.229 * * *$ & -0.043 & -0.118 & -0.029 & -0.036 & $-0.106^{*}$ & -0.074 & $-0.111 * *$ & -0.068 \\
\hline & $(0.034)$ & $(0.062)$ & $(0.055)$ & $(0.113)$ & $(0.041)$ & $(0.057)$ & $(0.064)$ & $(0.124)$ & $(0.050)$ & $(0.100)$ \\
\hline \multirow[t]{2}{*}{$y_{i, t-1} \ln \left(Y_{p c}\right)$} & $-0.056^{*}$ & 0.043 & 0.036 & 0.037 & 0.027 & 0.012 & $0.052 *$ & -0.007 & $0.136 * *$ & -0.006 \\
\hline & $(0.033)$ & $(0.045)$ & $(0.026)$ & $(0.058)$ & $(0.047)$ & $(0.017)$ & $(0.031)$ & $(0.075)$ & $(0.055)$ & $(0.031)$ \\
\hline \multirow[t]{2}{*}{$(\boldsymbol{k}-\boldsymbol{y})$} & -0.042 & 0.051 & -0.040 & 0.027 & 0.020 & $-0.072 *$ & -0.017 & -0.039 & -0.002 & $-0.057 * * *$ \\
\hline & $(0.037)$ & $(0.059)$ & $(0.053)$ & $(0.061)$ & $(0.025)$ & $(0.039)$ & $(0.015)$ & $(0.061)$ & $(0.048)$ & $(0.006)$ \\
\hline Hansen & 2.154 & 7.857 & 0.704 & 5.252 & 1.821 & 4.745 & 1.458 & 5.791 & 2.751 & 3.933 \\
\hline $\mathrm{p}$-value & 0.541 & 0.049 & 0.872 & 0.154 & 0.610 & 0.191 & 0.692 & 0.122 & 0.432 & 0.269 \\
\hline
\end{tabular}

*: significant at $10 \% ; * *$ :significant at $5 \%$; ***:significant at $1 \%$. 
Table B.2 - Estimation of Verdoorn's law through Sys-GMM by industry, controlled for schooling and tech gap

\begin{tabular}{|c|c|c|c|c|c|c|c|c|c|c|}
\hline & $q_{\text {Food }}$ & $q_{\text {Textiles }}$ & $q_{\text {Paper }}$ & $q_{\text {Fuels }}$ & $q_{\text {Chemicals }}$ & $q_{\text {Non-Met }}$ & $q_{\text {Metals }}$ & $q_{\text {Machinery }}$ & $q_{\text {Transport }}$ & $q_{\text {others }}$ \\
\hline \multirow[t]{2}{*}{$q_{i, t-1}$} & 0.151 & $0.464 * * *$ & 0.052 & 0.338 & $0.386 * * *$ & 0.428 & -0.045 & -0.009 & -0.115 & 0.119 \\
\hline & $(0.187)$ & $(0.172)$ & $(0.077)$ & $(0.46)$ & $(0.103)$ & $(0.265)$ & $(0.165)$ & $(0.069)$ & $(0.128)$ & $(0.162)$ \\
\hline \multirow{2}{*}{$y_{i}$} & $1.102 * * *$ & $2.125 * * *$ & $1.351 * *$ & $1.974 * *$ & $1.241 * * *$ & 0.336 & $2.366 * * *$ & 1.203 & $1.367 * * *$ & 1.298 \\
\hline & $(0.260)$ & $(0.466)$ & $(0.608)$ & $(0.923)$ & $(0.450)$ & $(0.618)$ & $(0.507)$ & $(1.748)$ & $(0.353)$ & $(0.816)$ \\
\hline \multirow[t]{2}{*}{$y_{i, t-1}$} & 0.411 & -0.538 & $-0.586 * *$ & -0.699 & -0.475 & -0.148 & $-0.556^{*}$ & 0.105 & $-1.057 * *$ & 0.069 \\
\hline & $(0.293)$ & $(0.381)$ & $(0.257)$ & $(0.872)$ & $(0.534)$ & $(0.476)$ & $(0.313)$ & $(1.148)$ & $(0.512)$ & $(0.328)$ \\
\hline \multirow[t]{2}{*}{$y_{i} \ln \left(Y_{p c}\right)$} & -0.034 & $-0.192 * * *$ & -0.092 & -0.113 & -0.040 & 0.040 & $-0.167 * * *$ & -0.074 & $-0.102 * *$ & -0.086 \\
\hline & $(0.032)$ & $(0.057)$ & $(0.062)$ & $(0.107)$ & $(0.046)$ & $(0.076)$ & $(0.055)$ & $(0.166)$ & $(0.042)$ & $(0.097)$ \\
\hline \multirow[t]{2}{*}{$y_{i, t-1} \ln \left(Y_{p c}\right)$} & $-0.064 * *$ & 0.034 & $0.059 * *$ & 0.041 & 0.008 & -0.025 & $0.049^{*}$ & -0.013 & $0.106^{*}$ & -0.019 \\
\hline & $(0.033)$ & $(0.041)$ & $(0.027)$ & $(0.056)$ & $(0.056)$ & $(0.060)$ & $(0.028)$ & $(0.114)$ & $(0.058)$ & $(0.033)$ \\
\hline \multirow[t]{2}{*}{$(\boldsymbol{k}-\boldsymbol{y})$} & $0.0365^{*}$ & 0.096 & -0.016 & 0.016 & 0.036 & -0.029 & -0.008 & -0.011 & 0.102 & $-0.063 * * *$ \\
\hline & $(0.021)$ & $(0.091)$ & $(0.054)$ & $(0.060)$ & $(0.04)$ & $(0.087)$ & $(0.013)$ & $(0.041)$ & $(0.073)$ & $(0.023)$ \\
\hline \multirow[t]{2}{*}{$H$} & 0.006 & $0.022 *$ & 0.006 & 0.021 & 0.010 & -0.002 & $0.032 * * *$ & $0.029 * *$ & -0.019 & 0.000 \\
\hline & $(0.010)$ & $(0.013)$ & $(0.008)$ & $(0.032)$ & $(0.009)$ & $(0.012)$ & $(0.012)$ & $(0.013)$ & $(0.027)$ & $(0.014)$ \\
\hline \multirow[t]{2}{*}{$G_{i}$} & $0.179 *$ & -0.099 & 0.115 & $-0.850^{*}$ & 0.060 & 0.158 & -0.159 & 0.455 & 1.420 & 0.828 \\
\hline & $(0.102)$ & $(0.191)$ & $(0.107)$ & $(0.495)$ & $(0.193)$ & $(0.169)$ & $(0.142)$ & $(0.924)$ & (1.051) & $(0.696)$ \\
\hline Hansen & 2.219 & 5.358 & 0.588 & 4.943 & 1.634 & 4.832 & 1.879 & 5.648 & 2.556 & 4.389 \\
\hline $\mathrm{p}$-value & 0.528 & 0.147 & 0.899 & 0.176 & 0.652 & 0.185 & 0.598 & 0.130 & 0.465 & 0.222 \\
\hline
\end{tabular}

